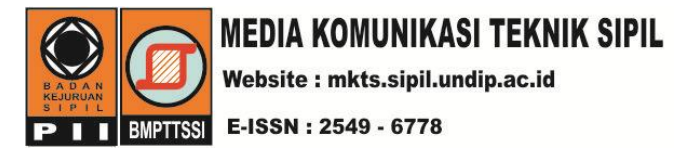

DOI: https://doi.org/10.14710/mkts.v23i2.16687

\title{
Korelasi Klasifikasi Penutup Lahan dengan Debit Puncak di Daerah Aliran Sungai
}

\author{
${ }^{*}$ Sri Sangkawati Sachro ${ }^{1}$, Sutarto Edhisono ${ }^{1}$, Pranoto Samto Atmodjo ${ }^{1}$, Wahyu Prasetyo ${ }^{2}$ \\ ${ }^{1}$ Departemen Teknik Sipil, Fakultas Teknik, Universitas Diponegoro Semarang \\ ${ }^{2}$ Balai Besar Wilayah Sungai Pemali-Juana \\ *)srisangkawati@gmail.com
}

Received: 30 November 2017 Revised: 12 Desember 2017 Accepted: 14 desember 2017

\begin{abstract}
Many studies have shown that land use changes in watersheds such as forests that convert to settlements, industrial and estates, have an impact on flooding. So it is important to know the correlation between the various land use changes to the discharge within a watershed. This study is a preliminary study in an attempt to assess the correlation between land cover index and peak discharge, with case studies in the Beringin River Basin.The peak discharge with return period of 2, 5, 10,20,50 and 100 years are computed with HEC-HMS software, developed by Hydrologic Engineering Centre (HEC) and US Army Corps of Engineers which computes the runoff discharge from the precipitation. As for land covered index (LCI), it is defined as the sum of the land-use index (LUI). The result of the case study shows the strong correlation between the land covered index with the the runoff discharge with such relation: $Q_{100}=-22.42 \mathrm{LCI}^{2}+214.30 \mathrm{LCI}-10.62$, $Q_{50}=-18.33 L C I^{2}+181.87 L C I-20.19, Q_{20}=-14.30 L C I^{2}+145.27 L C I-15.61, Q_{10}=-11.36 L C I^{2}+$ $118.41 L C I-12.29, Q_{5}=-8.42 L C I^{2}+91.27 L C I-8.9$ and $Q 2=-4.44 L C I^{2}+53.54 L C I-4.5$.
\end{abstract}

Keywords: Land use, peak discharge, river basin, land use index, land covered index

\begin{abstract}
Abstrak
Banyak studi yang menunjukkan bahwa perubahan guna lahan di daerah aliran sungai seperti hutan yang beralih fungsi menjadi pemukiman, industri dan pertania, berdampak terhadap meningkatnya banjir. Sehingga penting untuk diketahui korelasi antara perubahan berbagai guna lahan terhadap debit di dalam suatu daerah aliran sungai. Studi ini merupakan studi awal dalam upaya menilai korelasi antara indek tutupan lahan dengan debit puncak, dengan studi kasus di Daerah Aliran Sungai Beringin. Debit puncak dengan periode ulang 2, 5, 10, 20, 50 dan 100 tahun, dihitung menggunakan program HEC-HMS yang merupakan model pengalihragaman hujan menjadi aliran, yang dikembangkan oleh Hydrologic Engineering Centre (HEC) dari US Army Corps Of Engineers, dan indek tutupan lahan (land covered index, LCI) didefinisikan sebagai jumlah dari indek guna lahan (LUI). Hasil studi kasus yang dilakukan menunjukkan bahwa didapat hubungan yang kuat antara indek tutupan lahan dengan debit puncak dengan persamaan $Q_{100}=-22,42 L C I^{2}+214,30 L C I-10,62, Q_{50}=-18,33 L C I^{2}+181,87 L C I-20,19, Q_{20}=-14,30 L C I^{2}+$ $145,27 L C I-15,61, Q_{10}=-11,36 L C I^{2}+118,41 L C I-12,29, Q_{5}=-8,42 L C I^{2}+91,27 L C I-8,9$ dan $Q 2=-$ $4,44 L C I^{2}+53,54 L C I-4,5$.
\end{abstract}

Kata kunci: Guna lahan, debit puncak, daerah aliran sungai, indek guna lahan indek, tutupan lahan.

\section{Pendahuluan}

Seiring dengan berkembangnya jumlah penduduk dan meningkatnya aktivitas atau kegiatan masyarakat, akan memicu pertumbuhan kota dengan berbagai pembangunan di berbagai sektor, dan pembangunan sarana dan prasarana fisik adalah sektor yang cukup pesat perkembangannya. Pertumbuhan kota tersebut sering diiringi oleh pembukaan lahan untuk pemukiman, pemekaran daerah industri dan peruntukan lahan yang lain yang bermuara kepada perubahan tata guna lahan. Interaksi alam dari vegetasi, tanah dan air (hujan) disertai dengan intervensi manusia melalui usaha 
pengelolaan dan penggunaan teknologi membentuk karakteristik penggunaan lahan di daerah aliran sungai tersebut, sehingga terdapat klasifikasi penggunaan lahan yang merupakan pengelompokan agar lebih mudah dipahami.

Berdasarkan pertimbangan tertentu penggunaan lahan dikelompokkan menjadi sejumlah kategori. Di Indonesia klasifikasi penggunaan lahan sebagai acuan penyusunan peta penutup lahan daerah aliran sungai (DAS) belum baku. Salah satu acuan klasifikasi penutup lahan adalah berdasarkan SNI 7645:2010 yang dibedakan menjadi kelas penutup lahan skala 1:1.000.000; skala 1:250.000 dan skala $1: \leq 50.000$. kelas penutup lahan dibagi menjadi dua bagian besar, yaitu daerah bervegetasi dan daerah tidak bervegetasi. Kelas penutup lahan dalam kategori daerah bervegetasi diturunkan dari pendekatan konseptual struktur fisiognomi yang konsisten dari bentuk tumbuhan, bentuk tutupan, tinggi tumbuhan dan distribusi spasialnya. Sedangkan daerah tak bervegetasi pendekatan kelas mengacu pada aspek permukaan tutupan, distribusi atau kepadatan, dan ketinggian atau kedalaman obyek.

Sudah banyak penelitian yang menunjukkan adanya korelasi antara peningkatan banjir dengan alih fungsi lahan. Federal Interagency Stream Restoration Working Group memberiken referensi bahwa dalam kondisi alami, surface run-off berkisar antara 10 sampai 30\% dari curah hujan tahunan, dan infiltrasi bisa mencapai $50 \%$ tergantung pada tingkat perkembangan daearahnya. Pada kondisi lahan yang sudah berkembang, dimana permukaan impervious mencapai 35 sampai $50 \%$, aliran permukaan menjadi $35 \%$. Sedangkan pada permukaan impervious mencapai 75 sampai $100 \%$, aliran permukaan bisa meningkat menjadi $65 \%$. Perubahan karakteristik permukaan dapat mengganggu keseimbangan hidrologi alami sehingga menghasilkan kecepatan limpasan yang lebih tinggi yang dapat menyebabkan banjir dan membahayakan integritas ekologi sungai (FISRWG, 2001)

Ada korelasi antara peningkatan urbanisasi, persentase luas daerah dengan penutup kedap air seperti aspal, beton dan interval waktu terjadinya banjir. Beberapa efek hidrologi dari urbanisasi adalah: (1) meningkatnya permintaan air yang seringkali melebihi sumber daya alam yang ada; (2) meningkatnya air limbah, sehingga membebani sungai dan membahayakan ekologi; (3) peningkatan debit puncak; (4) mengurangi infiltrasi dan (5) mengurangi pengisian air tanah, meningkatkan penggunaan air tanah, dan mengurangi aliran dasar sungai (Mukherjee, 2016).
Penelitian dengan tujuan menilai bagaimana pengaruh urbanisasi terhadap limpasan permukaan yang dilakukan di Brussels Capital Region menunjukkan bahwa untuk setiap kenaikan $10 \%$ area permukaan kedap air mengakibatkan debit meningkat sebesar 32\%, limpasan kumulatif tahunan meningkat sebesar $40 \%$ dan frekuensi kejadian banjir meningkat sebesar 2,25 (Hamdi et al, 2010). Sebaliknya penghijauan menyebabkan peningkatan infiltrasi dan soil water retention potential (Wahren et al, 2009).

Perubahan tataguna lahan pada suatu daerah aliran sungai akan memberikan pengaruh pada besarnya limpasan permukaan dan debit banjir sungai. Simulasi banjir yang dilakukan di Nyando River basin (Kundu dan Olang, 2011) menunjukkan bahwa debit puncak di basin mengalami peningkatan yang signifikan, terutama di daerah hulu di mana tingkat deforestasi tinggi. Dalam studi tersebut, debit puncak meningkat sebesar $16 \%$ di semua 14 sub-catchment. Dalam skenario dimana sub-catchment terdiri dari $86 \%$ pertanian dan 5\% padang rumput meningkatkan debit puncak $14 \%, 13 \%, 1 \%$ berturut-turut untuk tinggi hujan $40 \mathrm{~mm}, 60 \mathrm{~mm}$ dan $80 \mathrm{~mm}$. Untuk tinggi hujan yang sama, pada skenario sub-catchment yang terdiri dari $10 \%$ pertanian dan $78 \%$ hutan dapat menurunkan debit puncak berturut-turut $27 \%, 26 \%, 25 \%$.

Daerah aliran Sungai Mella di Italy utara, kawasan hutan di daerah aliran sungai bagian atas meningkat 9\% sejak tahun 1954, karena penggunaan kayu untuk bahan bakar telah berkurang. Sedangkan daerah perkotaan meningkat $252 \%$, sementara luas daerah pertanian dan padang rumput menurun. Konsekuensi dari perubahan ini adalah limpasan permukaan berubah secara signifikan pada skala daerah aliran sungai, namun dengan sedikit penurunan puncak dan volume banjir (Ranzi et al, 2002).

Namun studi yang dilakukan di Sungai Brahmaputra India menunjukkan bahwa proyeksi perubahan iklim akan mempengaruhi kerentanan banjir lebih signifikan daripada perubahan tata guna lahan. Perubahan iklim dapat meningkatkan aliran puncak Sungai Brahmaputra sekitar 28\%, dan perubahan tata guna lahan dapat meningkatkan aliran sekitar 9\% (Ghosh and Dutta, 2011). Perubahan tata guna lahan di DAS Progo, Indonesia dapat dilihat dari peningkatan nilai curve number komposit pada kondisi basah yaitu pada tahun 2006 sebesar 83,5 menjadi 86,2 pada tahun 2010. Kenaikan 2,7\% ini mengakibatkan kenaikan debit sebesar 16,3\% (Maya, 2011). 
Perubahan tata guna lahan erat hubungannya dengan perubahan karakter penutup lahan yang merupakan salah satu komponen dari karakteristik daerah aliran sungai.

Perubahan salah satu karakter penutup lahan dapat mengakibatkan perubahan karakter transformasi secara keseluruhan. Mengingat perubahan guna lahan hutan secara keseluruhan tidak selalu menjadi lahan pertanian atau menjadi lahan pemukiman, demikian pula sebaliknya, serta perubahan satu guna lahan bisa menjadi banyak guna lahan lainnya maka perlu dilakukan rumusan korelasi antara kedua hal tersebut. Dalam artikel ini disajikan korelasi antara debit puncak (Q2, Q5, Q10, Q20, Q50 dan Q100) terhadap index perubahan tutupan lahan di daerah aliran sungai.

\section{Metode Penelitian}

Studi ini adalah untuk mencari korelasi antara debit puncak banjir dengan indek tutupan lahan di daerah aliran sungai (DAS) dengan studi kasus DAS Beringan. Penggunaan lahan di daerah tangkapan air tidak dapat dipisahkan dengan besarnya debit di sungai. Sebagai ekosistem alami yang merupakan fungsi dari karakteristik daerah aliran sungai seperti tipe tanah, tanaman penutup, dan tataguna lahan, maka perubahan satu karakter tutupan lahan dapat mengakibatkan perubahan secara keseluruhan. Tahapan studi ditunjukkan dalam Gambar 1

\section{Debit banjir}

Pendekatan empiris cukup banyak digunakan dalam penghitungan limpasan langsung (direct runoff), antara lain penggunaan metode SCS CN (Soil Conservation Service - Curve Number). Penggunaan metode SCS dalam menentukan hujan efektif menyertakan variabel $\mathrm{CN}$ yang merupakan fungsi dari karakteristik daerah aliran sungai. Meode SCS mengembangkan hubungan curah hujan dengan runoff, yaitu total curah hujan dibagi menjadi tiga komponen, direct runoff, actual retensi dan initial abstraction. Persamaan 1 (Chow, et all, 1988, McCuen, 1989), adalah persamaan dasar untuk menghitung runoff, $P_{e}$, dengan $P$, adalah kedalaman curah hujan, $I_{a}$, adalah initial abstraction dan $S$ sebagai potensial maximum retention. Persamaan 2 menunjukkan hubungan antara potensial maximum retention, $S$, dengan curve number, $C$.

$P_{e}=\frac{\left(P-I_{a}\right)^{2}}{\left(P-I_{a}\right)+S}$

$S=\left(\frac{1000}{C N}-10\right) \times 25,4 \mathrm{~mm}$
Dalam studi ini debit banjir dihitung berturut-turut dengan debit 2 tahun, 5 tahun, 10 tahun, 20 tahun, 50 tahun dan 100 tahun. Debit puncak dihitung menggunakan program HEC-HMS yang merupakan model pengalihragaman hujan menjadi aliran, yang dikembangkan oleh Hydrologic Engineering Centre (HEC) dari US Army Corps Of Engineers. Simulasi dalam program HEC-HMS ini mempunyai komponen model sebagai berikut: (1) model hujan (precipitation), (2) model losses untuk menghitung volume runoff, (3) model direct runoff (overland flow dan interflow), (4) model base flow, (6) model hydrologic routing (channel flow) dan (7) model water control measures, meliputi : diversion dan storage.

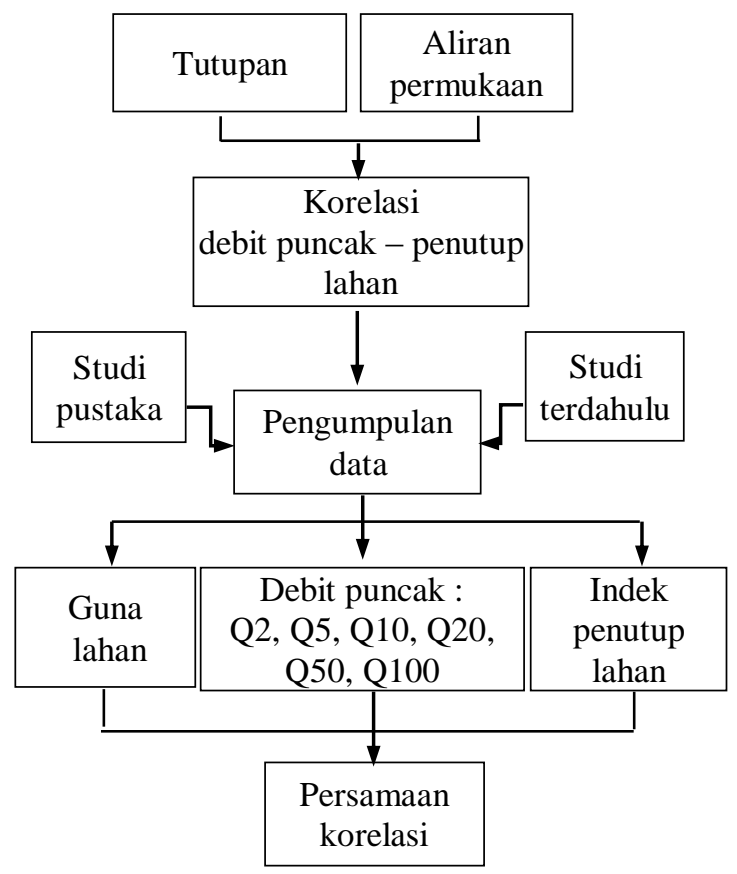

Gambar 1. Tahapan studi korelasi debit puncak-indek tutupan lahan

\section{Curve number}

Curve number adalah suatu index yang menyatakan/mewakili kombinasi hydrologic soil group dan land use and treatment. Secara empiris CN merupakan fungsi kelompok tanah, tutupan lahan dan kelembaban (McCuen, 1989). Persamaan 3 digunakan untuk memperkirakan curve number setiap sub-area dengan $A_{i}$ adalah luas peruntukan lahan $i$, dan $C N_{i}$ adalah curve number peruntukan lahan $i$ di sub-area.

$C N=\sum_{i=1}^{n} \frac{A_{i} C N_{i}}{\sum A_{i}}$

\section{Indek tutupan lahan}

Indek tutupan lahan (Land covered index, LCI) suatu area didefinisikan sebagai jumlah dari land 
use index (LUI). Sedangkan land use index adalah ratio luas guna lahan $\mathrm{i}\left(\mathrm{Lu}_{\mathrm{i}}\right)$ dibagi luas guna lahan $i$ di daerah aliran sungai $\left(\sum \mathrm{lu}_{\mathrm{i}}\right)$. LCI dan LUI ditentukan oleh Persamaan 4 dan Persamaan 5

$L C I=\sum_{i=1}^{n} L U I_{i}$

dimana,

$L U I_{i}=\frac{L u_{i}}{\sum_{i=1}^{n} L u_{i}}$

Indek tutupan lahan ditentukan berdasarkan guna lahan tahun 1995, 2005 dan 2015

\section{Studi kasus}

Daerah studi adalah di DAS Beringin yang terletak di Kota Semarang Provinsi Jawa Tengah, Indonesia dengan luas $\pm 33,841 \mathrm{~km}^{2}$. Sungai Beringin mengalir dari Gunung Ungaran di selatan menuju utara dan bermuara di Laut Jawa dengan ketinggian beragam dari hulu sampai hilir. Perubahan tata guna lahan dari tahun 1995' 2005 dan 2015 disajikan pada Gambar 2.

Berdasarkan peta guna lahan tahun 1995, 2005 dan 2015, guna lahan di DAS Beringan diklasifikasikan menjadi tujuh klas: (1) Hutan, terdiri dari lahan hutan dan lahan konservasi, (2) Industri, (3) Kota, termasuk di dalamnya adalah perdagangan dan jasa, masjid, pasar, sekolah, pemukiman, (4) Pertanian, meliputi pertanian basah dan pertanian kering, (5) Taman, meliputi taman, olah raga dan rekreasi dan tempat pemakaman umum, (6) Ruang terbuka non hijau (RTNH), seperti terminal, jalan (7), kolam, meliputi tambak dan waduk. Tabel 1 menunjukkan perubahan luas guna lahan dalam tujuh klas tersebut.
Tabel 1. Luas guna lahan di DAS Beringin

\begin{tabular}{llrrr}
\hline \multirow{2}{*}{ No Guna lahan } & \multicolumn{3}{c}{ Luas $(\boldsymbol{\%}))$} \\
\cline { 2 - 4 } & $\mathbf{1 9 9 5}$ & $\mathbf{2 0 0 5}$ & $\mathbf{2 0 1 5}$ \\
\hline 1 Hutan & 3,22 & 27,28 & 23,54 \\
2 Industri & - & 10,59 & 10,23 \\
3 Pemukiman & 11,72 & 35,16 & 46,11 \\
4 Pertanian & 810 & 18,26 & 15,41 \\
5 & Taman & 4,06 & 5,84 & 1,84 \\
6 & RTNH & - & 0,08 & 0,74 \\
7 & Waduk/tambak & 2,89 & 2,79 & 2,12 \\
\hline
\end{tabular}

Penggunaan lahan di DAS Beringin dari tahun ke tahun terus mengalami perubahan. Luas hutan pada 2015 berkurang hingga $67,78 \%$ dari luas hutan 1995, sebaliknya guna lahan pemukiman peningkatan sangat tinggi. Luas guna lahan pemukiman selama kurun waktu 1995 - 2005 sebesar 192,25\%, dan selama kurun waktu 20052015 sebesar 34,95\%. Peningkatan pemukiman ini menjadi $294,27 \%$ bila dihitung selama kurun waktu 1995-2015.

\section{Hasil dan Diskusi}

\section{Curve Number}

Dalam penilaian hydrologic soil group dan land use and treatment $(\mathrm{CN})$, DAS Beringin dibagi ke dalam 31 basin, dengan luas terbesar adalah 9,202 $\mathrm{km}^{2}$ dan luas terkecil adalah $0,083 \mathrm{~km}^{2}$. Indek yang mewakili kombinasi di DAS Beringin ditunjukkan dalam Gambar 3. Nilai CN rata-rata 2005 naik $1.88 \%$ dari Cn rata-rata 1995 , sedang nilai $\mathrm{CN}$ rata-rata 2015 naik $2.87 \%$ dari $\mathrm{CN}$ ratarata 2005. Dalam kurun waktu 20 tahun (1995 2015), nilai $\mathrm{CN}$ rata-rata di Beringin river basin meningkat $4.8 \%$, dengan kenaikan tertinggi di Basin-1, yaitu $16.14 \%$.

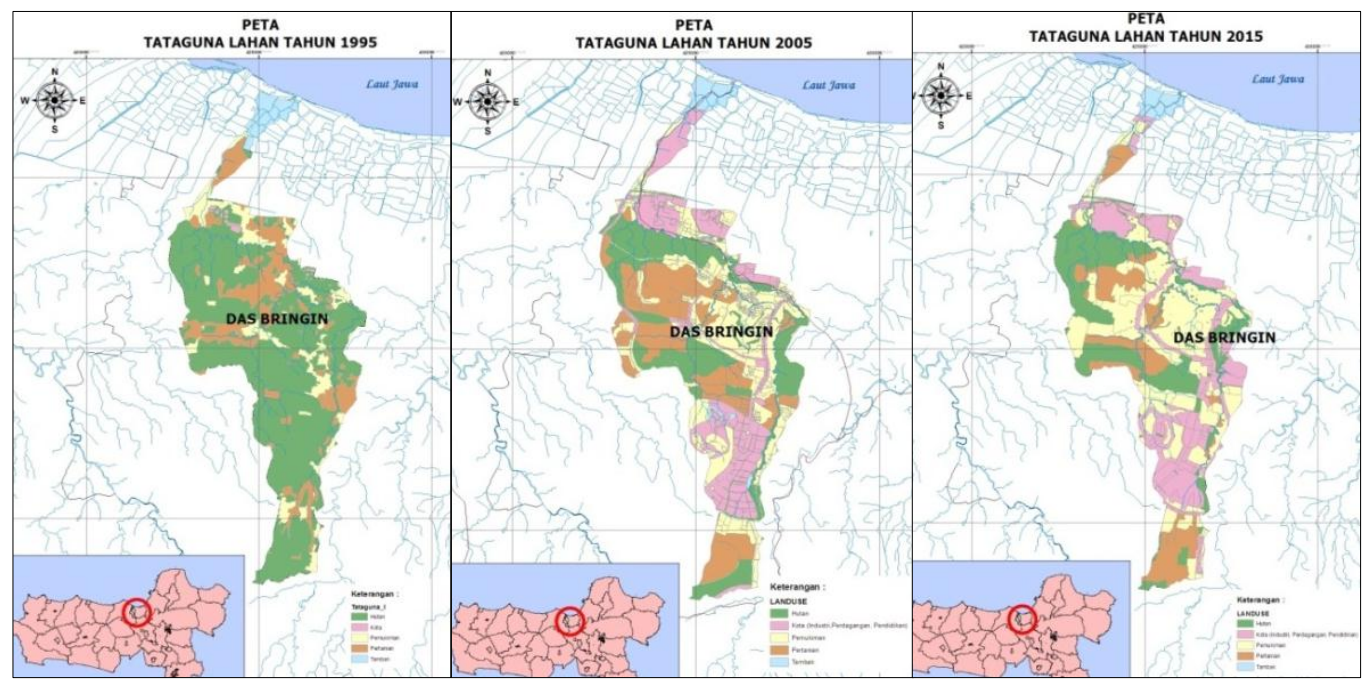

Gambar 2. Peta tata guna lahan DAS Beringin (BBWS Pemali Juana, 2016) 


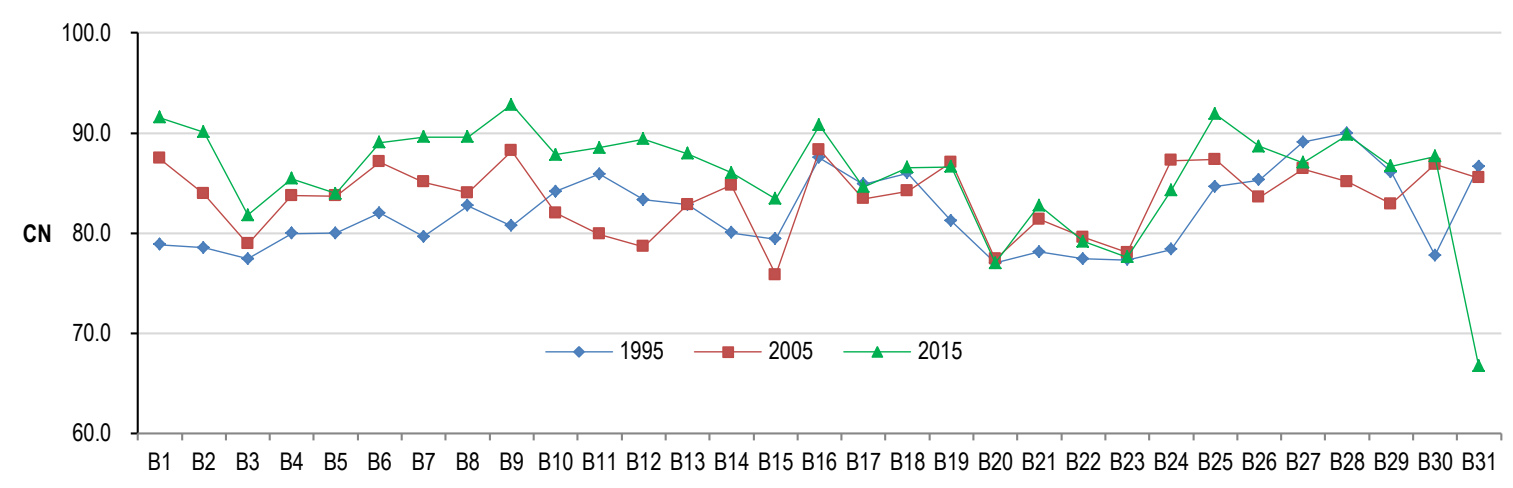

Sub basin

Gambar 3. Curve number di 31 basin
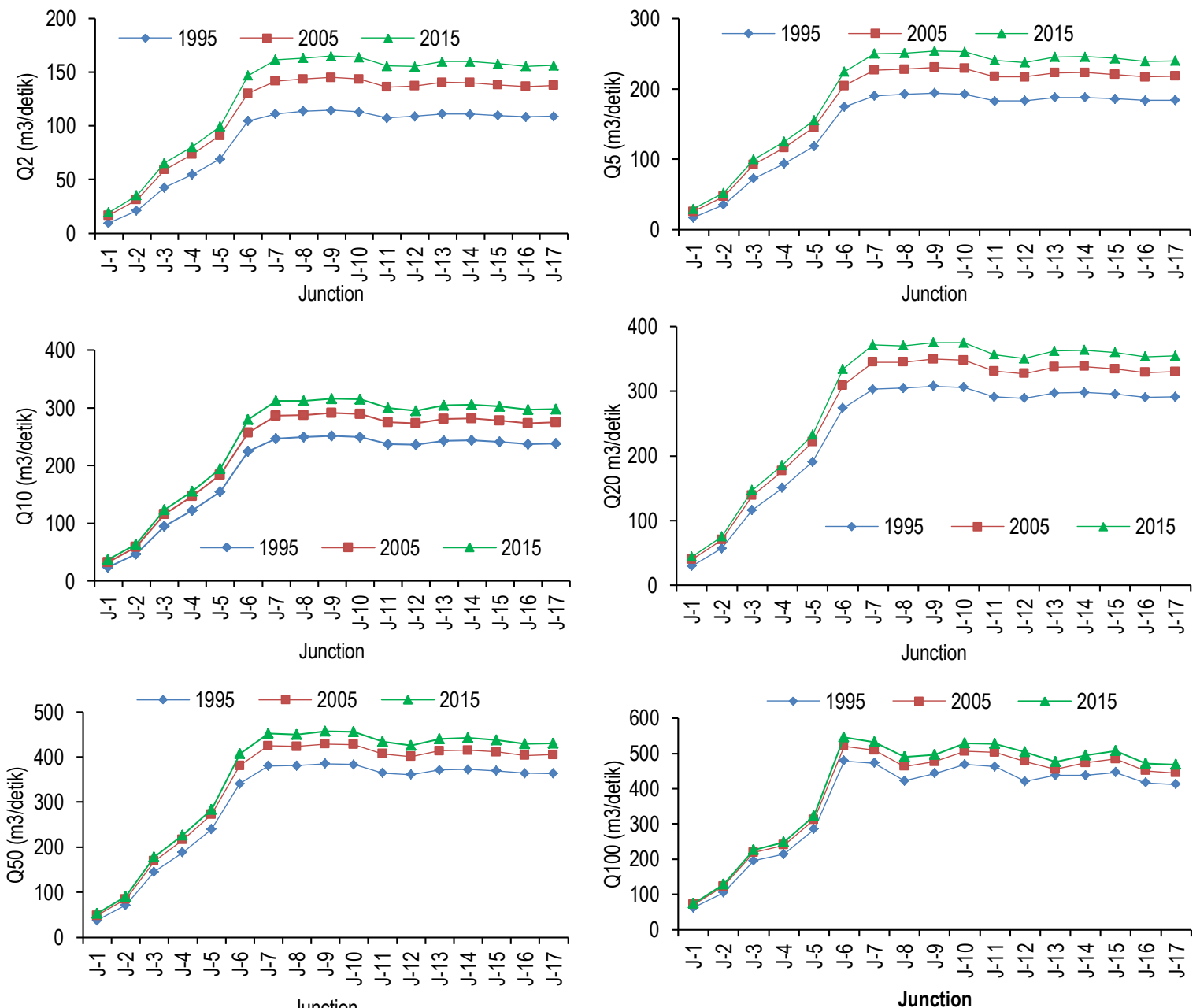

Junction

$$
\text { Junction }
$$

Gambar 4. Perubahan debit puncak 1995, 2005, 2015

Sebagai yang ditunjukkan dalam Gambar 3, curve number naik lebih dari $10 \%$ terjadi di lima basin, yaitu B1, B9, B2, B30 dan B7. Curve number Basin-1 pada 1995 adalah 78.83 meningkat menjadi 91.56 pada tahun 2015 atau naik $15 \%$. Kenaikan tertingi kedua dan ketiga, berturut-turut adalah di B-9 naik $14.72 \%$ dari 80.73 menjadi 92.84, dan di B-2 naik $14.72 \%$ dari 78.54 pada 1995 menjadi 90.10 pada 2015. Nilai $\mathrm{CN}$ yang relatif tidak mengalalmi perubahan dari 1995, 2005 dan 2015 adalah di Basin-20, yaitu berturut-turut 77,00; 77,37 dan 77,00.

\section{Debit puncak}

Nilai CN sebagai variabel penentu perubahan lahan di DAS yang mempengaruhi kondisi hidrologi dalam pengalihragaman hujan menjadi 
aliran, yang menentukan seberapa besar limpasan yang terjadi. Debit di wilayah studi dihitung dengan kedalaman hujan $23.22 \mathrm{~mm}, 127.33 \mathrm{~mm}$, $33.1 \mathrm{~mm}$ and $18.48 \mathrm{~mm}$.

Untuk menilai hubungan antara indek tutupan lahan dengan debit puncak, DAS Beringin dibagi ke dalam 17 area (satu area di muara sungai), yang ditandai dengan suatu juntion, yaitu persimpangan dimana besarnya aliran merupakan gabungan aliran dari elemen-elemen di hulu persimpangan. Dengan program HEC-HMS, debit berdasarkan guna lahan 1995, 2005 dan 2015 di 16 junction disajikan dalam Gambar 3.

Peningkatan debit selama 15 tahun dari 1995-2015 terjadi di semua basin. Peningkatan debit puncak, Q2 selama lima tahun dari 1995 sampai 2005 adalah 26,27\%-72,92\%, dan tahun 2005-2015 naik 9,34-18,07\%. Peningkatan Q5 selama tahun 19952005 adalah $17,23-48,30 \%$ dan kenaikan tahun 2005-2015 adalah 7,12-13,79\%.

Peningkatan debit puncak tahun 1995-2005 dengan periode ulang lebih besar, Q10 dan Q20, Q50 dan Q100 berturut-turut adalah; 14,34-39,15\%; 12,89$33,67 \%$; 10,85-28,19; 7,42-12,88\%. Sedangkan peningkatan debit puncak tahun 2005-2015 berturut-turut adalah 5,82-12,23\%; 5,05-10,94\%; $4,30-9,34 \%$ dan $3,04-5,74 \%$.

\section{Indek tutupan lahan}

Indek tutupan lahan didefinisikan sebagai jumlah dari land use index (LUI) dan ditentukan dengan Persamaan 4 dan Persamaan 5. Tabel 2 menunjukkan land use index dan land covered index di masing-masing junction tahun 1995, 2005 dan 2015.

\section{Korelasi indek tutupan lahan dengan debit puncak}

Korelasi antara indek tutupan lahan (LCI) dengan debit puncak (Q) dibangun berdasarkan indeks tutupan lahan pada Tabel 2 dan debit puncak sebagai yang ditunjukkan dalam Gambar 3 . Korelasi keduanya disajikan pada Gambar 4. Tampak bahwa trendline debit puncak terhadap LCI tahun 1995, 2005 dan 2015 menunjukkan trend yang sama, dan mempunyai korelasi yang kuat.

Secara matematik korelasi kedua variable tersebut diberikan berturut-turut oleh Persamaan 6-8 untuk $\mathrm{Q}_{100}$ terhadap LCI dari guna lahan 1995, 2005 dan 2015. Persamaan 7 untuk peta guna lahan 2005 dan Persamaan 8 untuk peta guna lahan 2015.

Tabel 2. Land use index dan land covered index di daerah aliran sungai Beringin, Indonesia

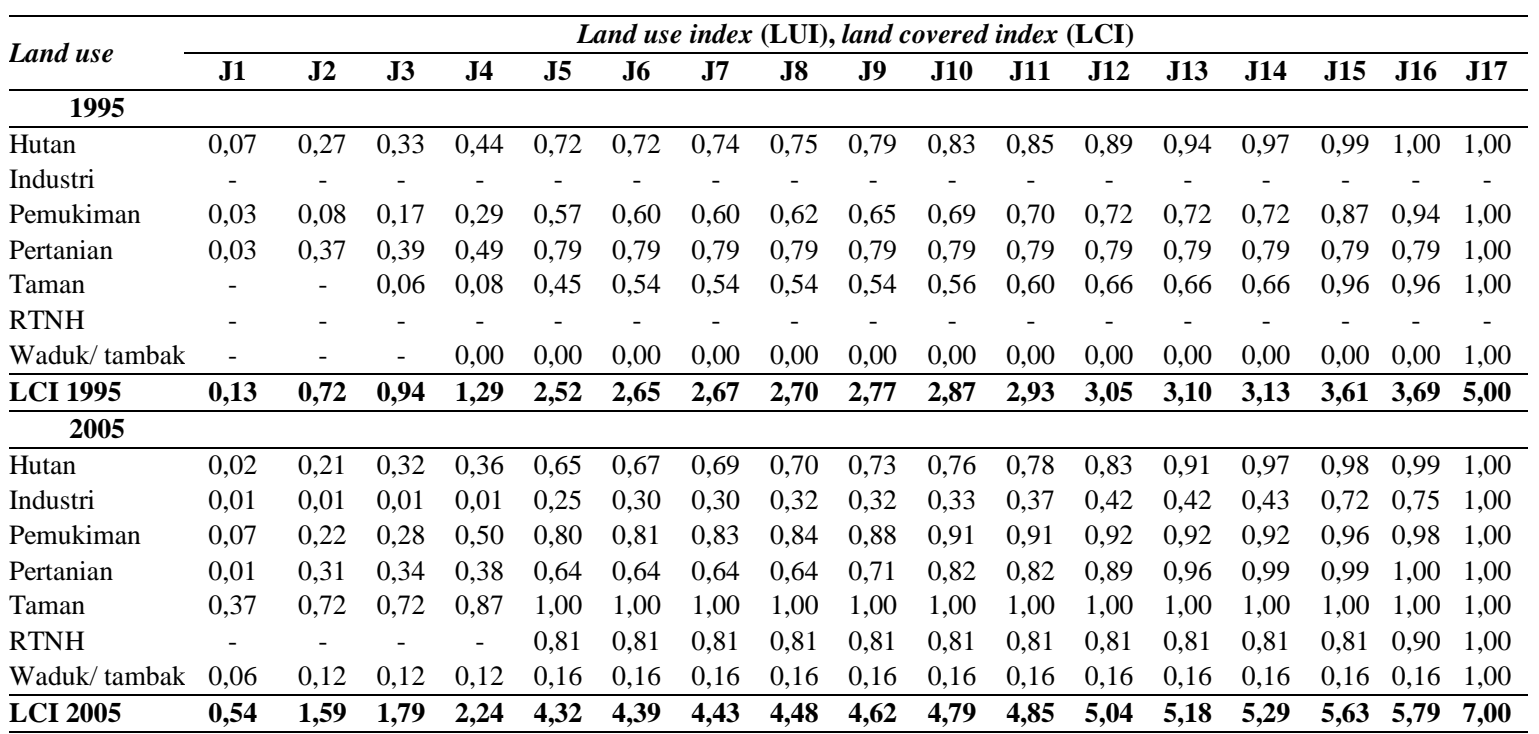

\begin{tabular}{|c|c|c|c|c|c|c|c|c|c|c|c|c|c|c|c|c|c|}
\hline 2015 & & & & & & & & & & & & & & & & & \\
\hline Hutan & 0,03 & 0,27 & 0,35 & 0,38 & 0,57 & 0,58 & 0,59 & 0,59 & 0,62 & 0,65 & 0,68 & 0,75 & 0,86 & 0,96 & 0,98 & 1,00 & 1,00 \\
\hline Industri & - & - & - & - & 0,53 & 0,57 & 0,57 & 0,59 & 0,59 & 0,60 & 0,64 & 0,68 & 0,68 & 0,69 & 0,95 & 0,96 & 1,00 \\
\hline Pemukiman & 0,09 & 0,27 & 0,33 & 0,52 & 0,78 & 0,79 & 0,81 & 0,82 & 0,87 & 0,90 & 0,90 & 0,91 & 0,92 & 0,92 & 0,95 & 0,97 & 1,00 \\
\hline Pertanian & 0,00 & 0,17 & 0,24 & 0,30 & 0,65 & 0,65 & 0,65 & 0,66 & 0,71 & 0,78 & 0,78 & 0,86 & 0,90 & 0,90 & 0,90 & 0,91 & 1,00 \\
\hline Taman & 0,26 & 0,95 & 0,95 & 0,95 & 0,98 & 0,98 & 0,98 & 0,98 & 0,98 & 0,98 & 0,98 & 0,98 & 0,98 & 0,98 & 0,98 & 0,98 & 1,00 \\
\hline RTNH & 0,03 & 0,04 & 0,04 & 0,04 & 0,44 & 0,44 & 0,44 & 0,44 & 0,44 & 0,44 & 0,44 & 0,44 & 0,44 & 0,44 & 0,44 & 0,44 & 1,00 \\
\hline
\end{tabular}


$\mathrm{Q}_{100}=-43,33 \mathrm{LCI}^{2}+272,70 \mathrm{LCI}+23,06$

$\mathrm{Q}_{100}=-23,03 \mathrm{LCI}^{2}+228,10 \mathrm{LCI}-76,51$

$\mathrm{Q}_{100}=-17,43 \mathrm{LCI}^{2}+208,12 \mathrm{LCI}-75,76$

Persamaan matematik korelasi $\mathrm{Q}_{50}$ terhadap LCI dari guna lahan 1995, 2005 dan 2015 diberikan oleh Persamaan 9-11.

$\mathrm{Q}_{50}=-37,14 \mathrm{LCI}^{2}+233,99 \mathrm{LCI}+6,21$
$\mathrm{Q}_{50}=-19,52 \mathrm{LCI}^{2}+196,13 \mathrm{LCI}-76,35$
$\mathrm{Q}_{50}=-14,43 \mathrm{LCI}^{2}+179,34 \mathrm{LCI}-75,64$

Persamaan matematik korelasi $\mathrm{Q}_{25}, \mathrm{Q}_{20}, \mathrm{Q}_{10}, \mathrm{Q}_{5}$ dan $\mathrm{Q}_{2}$ terhadap LCI dari guna lahan 1995, 2005 dan 2015 berturut-turut diberikan oleh, Persamaan 12-14, Persamaan 15-17, Persamaan 18-20, Persamaan 21-23 dan Persamaan 24-26.

$$
\begin{aligned}
& \mathrm{Q}_{20}=-29,58 \mathrm{LCI}^{2}+186,97 \mathrm{LCI}+4,60 \\
& \mathrm{Q}_{20}=-15,82 \mathrm{LCI}^{2}+159,17 \mathrm{LCI}-61,21 \\
& \mathrm{Q}_{20}=-11,73 \mathrm{LCI}^{2}+146,71 \mathrm{LCI}-61,18 \\
& \mathrm{Q}_{10}=-24,03 \mathrm{LCI}^{2}+152,41 \mathrm{LCI}+3,51 \\
& \mathrm{Q}_{10}=-13,11 \mathrm{LCI}^{2}+132,01 \mathrm{LCI}-50,27 \\
& \mathrm{Q}_{10}=-9,75 \mathrm{LCI}^{2}+122,56 \mathrm{LCI}-50,59 \\
& \mathrm{Q}_{5}=-18,43 \mathrm{LCI}^{2}+117,49 \mathrm{LCI}+2,42 \\
& \mathrm{Q}_{5}=-10,38 \mathrm{LCI}^{2}+104,54 \mathrm{LCI}-39,32 \\
& \mathrm{Q}_{5}=-7,71 \mathrm{LCI}^{2}+97,75 \mathrm{LCI}-39,71 \\
& \mathrm{Q}_{2}=-10,67 \mathrm{LCI}^{2}+68,88 \mathrm{LCI}+1,01 \\
& \mathrm{Q}_{2}=-6,51 \mathrm{LCI}^{2}+65,49 \mathrm{LCI}-23,96 \\
& \mathrm{Q}_{2}=-4,87 \mathrm{LCI}^{2}+62,62 \mathrm{LCI}-24,69
\end{aligned}
$$

Gambar 6 adalah korelasi antara debit puncak dengan LCI yang dibangun berdasarkan hasil hitungan debit dengan periode $2,5,10,20,50$ dan 100 tahun, untuk guna lahan 1995, 2005 dan 2015. Seperti yang ditunjukkan pada Gambar 5, trendline pada Gambar 6 ini juga menunjukkan korelasi yang sangat kuat. Persamaan 24 sampai 26 menunjukkan hubungan indek tutupan lahan dengan debit puncak di DAS Beringin.

$$
\begin{aligned}
& \mathrm{Q}_{100}=-22,42 \mathrm{LCI}^{2}+214,30 \mathrm{LCI}-10,62 \\
& \mathrm{Q}_{50}=-18,33 \mathrm{LCI}^{2}+181,87 \mathrm{LCI}-20,19 \\
& \mathrm{Q}_{20}=-14,30 \mathrm{LCI}^{2}+145,27 \mathrm{LCI}-15,61
\end{aligned}
$$

$$
\begin{aligned}
& \mathrm{Q}_{10}=-11,36 \mathrm{LCI}^{2}+118,41 \mathrm{LCI}-12,29 \\
& \mathrm{Q}_{5}=-8,42 \mathrm{LCI}^{2}+91,27 \mathrm{LCI}-8,9 \\
& \mathrm{Q}_{2}=-4,44 \mathrm{LCI}^{2}+53,54 \mathrm{LCI}-4,5
\end{aligned}
$$

dimana, Q adalah debit puncak di basin, LCI adalah indek tutupan lahan. yang dapat ditentukan dengan menggunakan Persamaan 4.

Makin besar nilai indek tutupan lahan, debit juga makin besar. Grafik hubungan antara LCI dengan debit puncak seperti yang ditunjukkan dalam Gambar 5 dan Gambar 6 menunjukkan nilai LCI maksimum 5,04. Pada nilai LCI lebih dari 5,04 terjadi penurunan grafik. Hal ini diakibatkan oleh penurunan debit mulai dari juction 14 sampai muara (Tabel 2).

Ada korelasi antara peningkatan debit banjir dengan alih fungsi lahan (FISRWG, 2001; Mukherjee, 2016; Kundu dan Olang, 2011), dan dalam persamaan yang menunjukkan korelasi tersebut dapat dinyatakan oleh Persamaan 24 - 29.

Studi ini merupakan upaya untuk menilai hubungan antara guna lahan yang dinyatakan dalam indek tutupan lahan yang terdiri dari tujuh indikator guna lahan dengan debit puncak, dengan studi kasus di DAS Beringin. Dalam studi kasus ini, data guna lahan 1995, 2005 dan 2015 mempunyai klasifikasi tidak sama, sedangkan untuk menentukan indek guna lahan diperlukan klasifikasi guna lahan yang sama. Diharapkan, evaluasi guna lahan dari waktu ke waktu di suatu daereah aliran sungai dapat menggunakan klasifikasi yang sama.

\section{Kesimpulan}

Studi ini untuk mengetahui korelasi indek tutupan lahan dengan debit puncak dengan kasus di DAS Beringin telah dilakukan, maka dapat disimpulakn bahwa terdapat hubungan yang erat dari indek tutupan lahan dengan debit puncak, meskipun masing-masing daerah aliran sungai mempunyai karakteristik yang berbeda, korelasi indek tutupan lahan dengan debit puncak dengan periode 2, 5, 10, 20, 50 dan 100 tahun bisa didekati dengan Persamaan 24 sampai 29 dan studi dengan lokasi yang berbeda perlu dikembangkan, untuk mengetahui apakah Persamaan 24 sampai 29 dapat diterapkan secara universal 

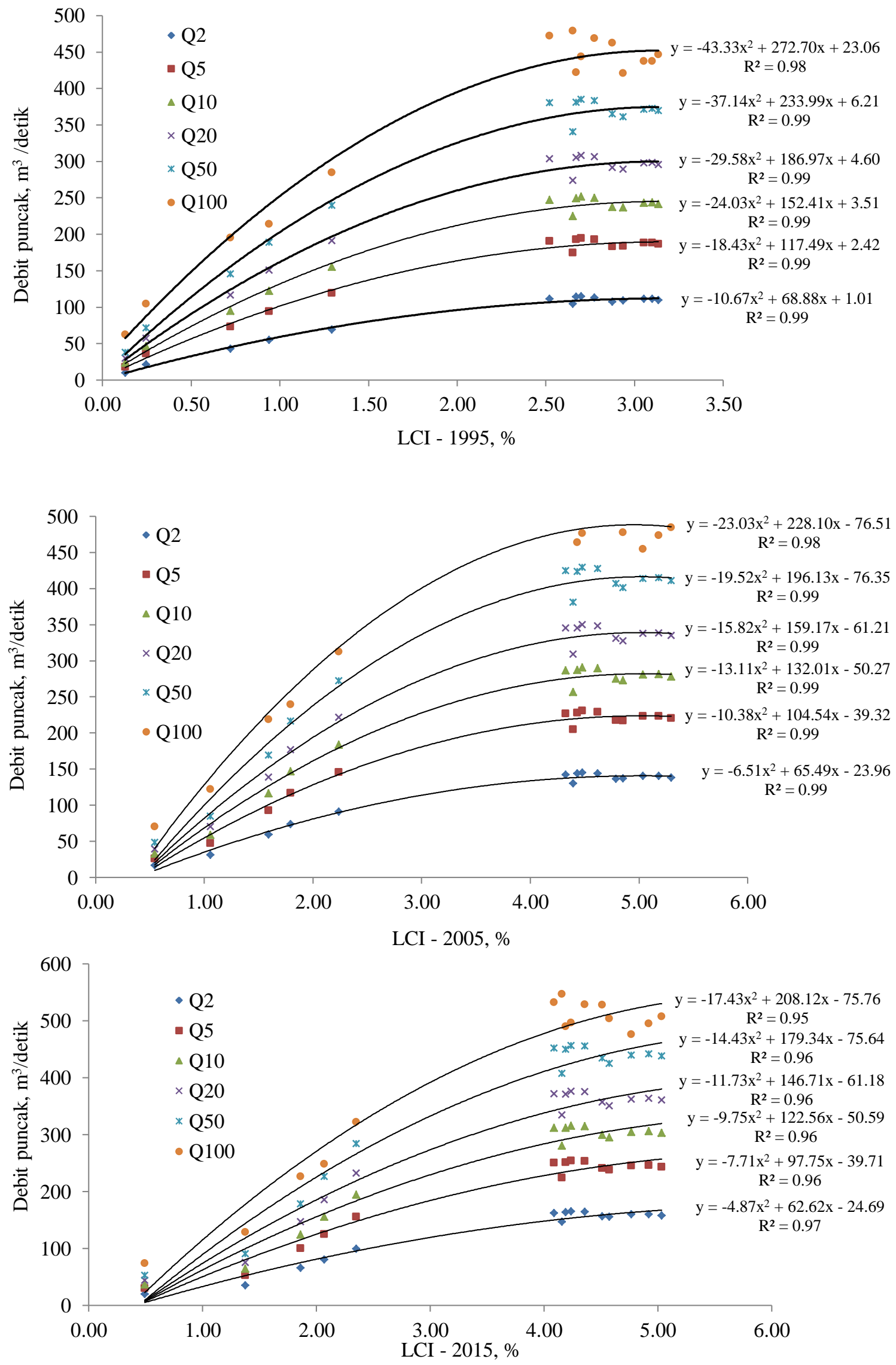

Gambar 5. Hubungan debit dengan LCI 1995, 2005 dan 2015 di DAS Beringin 


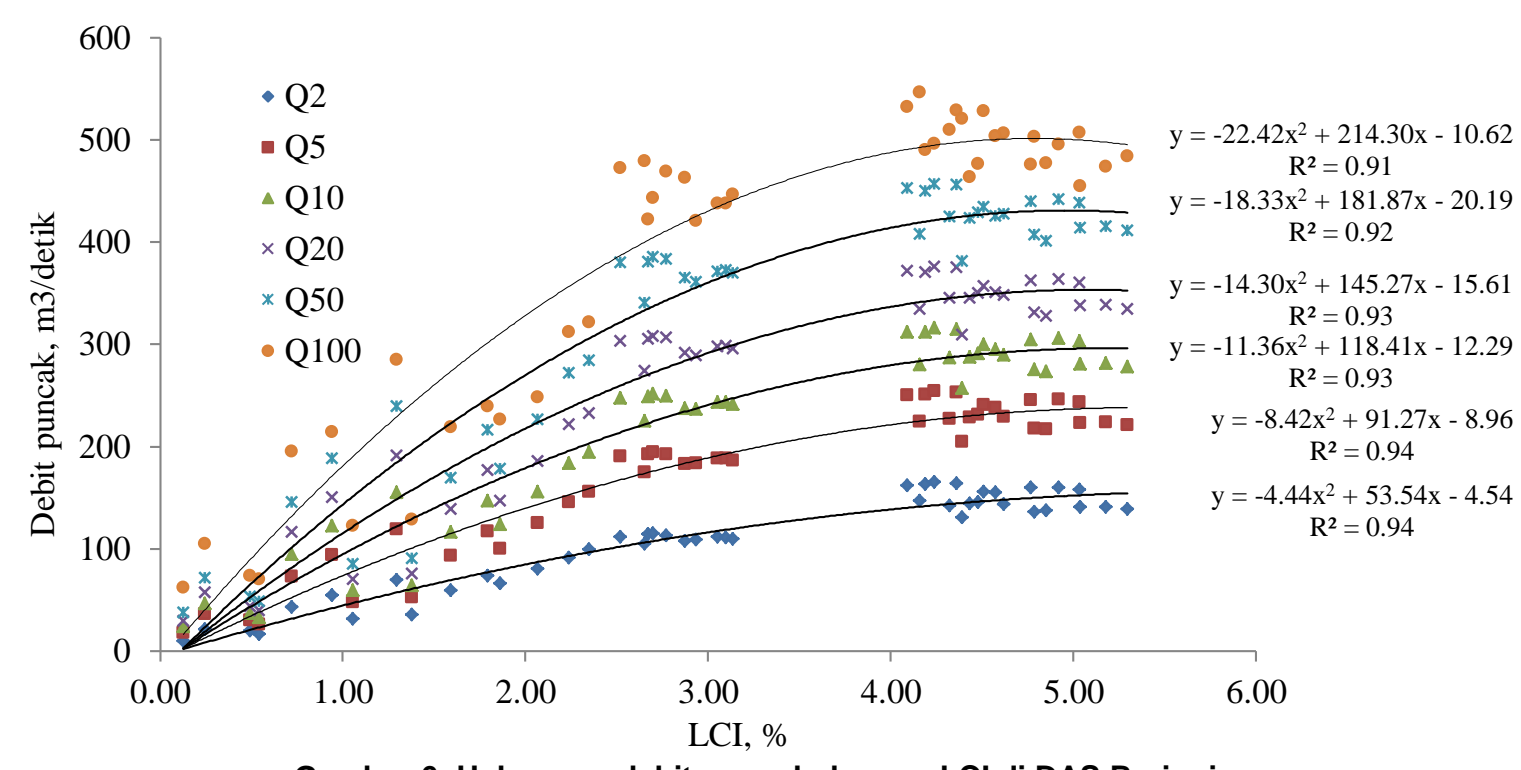

Gambar 6. Hubungan debit puncak dengan LCI di DAS Beringin.

\section{Daftar Pustaka}

FISRWG. 2001. Stream Corridor Restoration: Principles, Processes, and Practices. National Engineering Handbook, USDA - Natural Resources Conservation Service.

Badan Standardisasi Nasional (BSN), 2010, Klasifikasi Penutup Lahan, Standard Nasional Indonesia, SNI 7645:2010

Mukherjee, D., 2016, Effect Of Urbanization On Flood - A Review With Recent Flood In Chennai (India), International Journal of Engineering Sciences \& Research Technology, 5(7), 451-455 http: // www.ijesrt.com

Hamdi, R., Termonia, P., \& Baguis, P. (2011). Effects of urbanization and climate change on surface runoff of the Brussels Capital Region: a case study using an urban soil-vegetationatmosphere-transfer model. International Journal of Climatology, 31(13), 1959-1974.

Kundu, P. M., \& Olang, L. O. (2012). The impact of land use change on runoff and peak flood discharges for the Nyando River in Lake Victoria drainage basin, Kenya. Water and Society, 153, 83., doi:10.2495/WS110081-2011
Wahren, A., Feger, K. H., Schwärzel, K., \& Münch, A. (2009). Land-use effects on flood generation-considering soil hydraulic measurements in modelling. Advances in Geosciences, 21, 99.

Ranzi, R., Bochicchio, M., \& Bacchi, B. (2002). Effects on floods of recent afforestation and urbanisation in the Mella River (Italian Alps). Hydrology and Earth System Sciences, 6(2), 239-254.

Ghosh, S., \& Dutta, S. (2011, January). Impact of Climate and Land Use Changes on the Flood Vulnerability of the Brahmaputra Basin. In Geospatial world forum (pp. 18-21).

Amalia, M. (2016). Analisa Peningkatan Nilai Curve Number Terhadap Debit Banjir Daerah Aliran Sungai Progo. Info-Teknik, 12(2), 35-39.

Chow, V.T., Maidment, D.R., and mays, L.W., Applied Hydrology, Mcgraw-Hill, New York, USA, USA, 1988.

McCuen, Richard H, Hydrologic Analysis and Design, Prentice Hall, Englewood Cliffs, New Jersey, 1989. 